\title{
Religiosity and Conflict Handling Styles: A Study of a Muslim Community
}

\author{
MOHAMMAD TAHLIL AZIM ${ }^{1}$
}

\begin{abstract}
This is a pioneering study to address the Islamic view of conflict and the preference of using conflict handing styles by the Devotee Muslims in Saudi Arabia. Independent sample T-test and paired T-test were run using SPSS version 16.0. The study reveals that there is a striking disparity between the Islamic directives and the preference of the self-claimed devotee Muslims. The prohibited dominating style turns out to be the second most preferred style whereas the most encouraged obliging style is observed to be the second least preferred style for the devotee Muslims. It indicates that the selfclaimed devotee Muslims have a lack of knowledge or comprehension about the breadth of Islam which implies that the Islamic scholars and the community leaders should emphasize on the totality of Islam through speeches, actions, and education. The study suggests that in-depth studies are required to explore the psychic makeup of Muslims as regards worship vis-a-vis interpersonal relationships.
\end{abstract}

Keywords: conflict, conflict management, religiosity, religious conflict, Saudi Arabia

Conflict is an inevitable social phenomenon. Interpersonal conflict is very much part of our life. Putnam and Poole (1987: 552) define conflict as "the interaction of interdependent people who perceive opposition of goals, aims, and values, and who see the other party as potentially interfering with the realization of these goals." Rahim (2001) views Interpersonal conflict as "the manifestation of incompatibility, disagreement, or a difference between two or more interacting individuals." People differ in their approaches and skills to handle conflict (Ruble \& Schneer 1994; Boonsathorn 2007). Conflict handling style refers to a general and steady approach toward the other party as regard conflict resolution, which is reflected in a person's behaviors (Thomas 1976). A person's conflict handling style depends on an array of factors including culture, biographic characteristics, social/organizational status, religion, and others.

The way individuals perceive conflict is considerably affected by culture (Hofstede 1980). Culture also affects the choice of conflict handling style (Tjosvold \& Wong 2004). Many studies (Chua \& Gudykunst 1987; Elsayed-Ekhouly \& Buda 1996; Morris et al. 1998; Ting-Toomey et al., 2000; He, Zhu, and Peng 2001) have established that conflict-handling styles differ in line with the culture. Studies investigating conflict-handling styles along the cultural context and individualismcollectivism dimensions suggest that people from high-context and collectivistic cultures tend to be more avoiding and accommodating and less competing and confrontational than people from low context and individualistic cultures (Dsilva \& Whyte 1998). Religion is also considered as a determining factor for the choice of conflict handling styles. Among many factors, religion constitutes an essential part of a culture (Geertz 1973). For many individuals, it is the most

\footnotetext{
${ }^{1}$ Mohammad Tahlil Azim, Ph.D., assoc. professor at the Department of Business Administration, Faculty of Economics and Administration, King Abdulaziz University, JEDDAH 21589, Saudi Arabia, email: tahlilazim@yahoo.com.
}

https://doi.org/10.24035/ijit.12.2017.002 
important cultural identifier (Alston 1975). A good number of studies (Alston 1975; Geertz 1973; Randeree 2008; Polkinghorn \& Byrne 2001; Wilson \& Power 2004; Croucher 2011; Wekhian 2015) explored the relationship between religious affiliation or religiosity and the conflict handling styles.

Islam, a prominent world religion, has a domineering influence over the life of its followers. It is not confined to faith only. Rather it encourages its members to practice the religious dos and don'ts in every aspect of their lives (Wekhian 2015). 'Conflict' is also not an exception. There are specific instructions as regard handling conflict in Islam. However, so far, no serious attempt to explore the Islamic view of conflict is observed in the literature. The existing studies (For example, Wilson \& Power 2004; Croucher 2011; Wekhian 2015) simply explored the association between the conflict handling styles and the religious affiliation or religiosity of the respondents, without explaining the underlying reasons behind such relationship from the Islamic perspective. Hence, there is a noticeable gap in research to explore the Islamic view of conflict and the practice of the Muslims. Oetzel et al. (2006) also admitted that there is an apparent lack of conflict-research in the Muslim world. Keeping this research space in mind, the present study is set out to explore conflict from the Islamic perspective and the practice of a Muslim community as regard their adherence to the religious instructions concerning the conflict.

\section{Literature Review and Hypotheses Development}

\section{Conflict Handling Styles}

Conflicts can be handled in a variety of ways. There are variations in the typology of conflict handling styles. However, Rahim \& Bonoma's (1979) typology based on the original work of Blake and Mouton (1964) has been observed to be the most popular. Anchored in two dimensions of the disputants' concern: (a) concern for self and (b) concern for others, Rahim \& Bonoma (1979) identified five different styles as depicted in figure 1: integrating, obliging, dominating, avoiding, and compromising.

Figure 1: Conflict Handling Styles

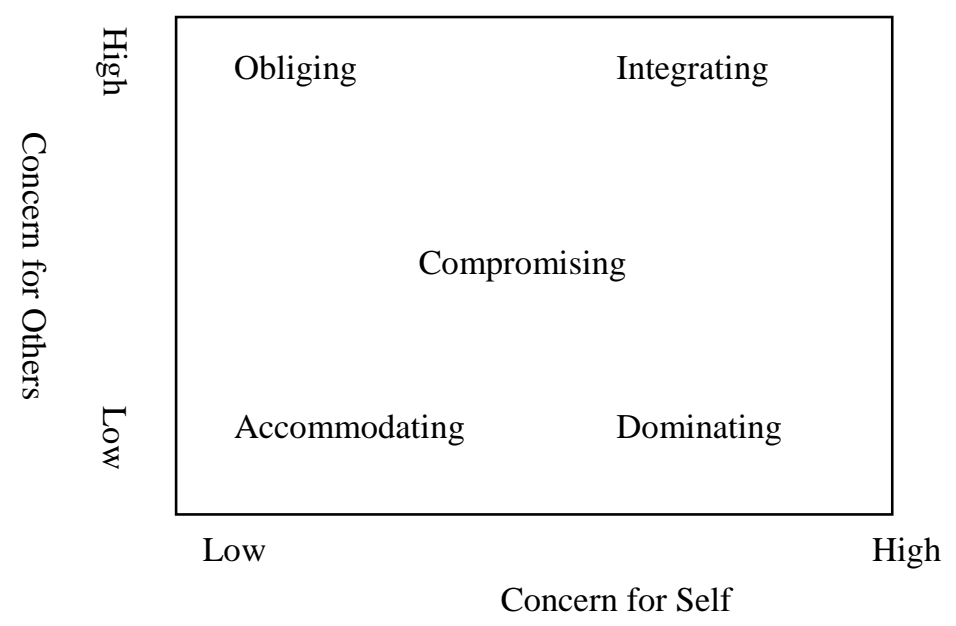

We may conceptualize these five styles as follows: (1) Integrating (high concern for self and others) style refers to mutually favorable solutions to the disputants. Here the parties try to develop 'win-win' situation through creativity, Flexibility, exchange of information and open communication. (2) Obliging (low concern for self and high concern for others) style implies 
overwhelming concern for maintaining an interpersonal relationship (Folger, Poole \& Stutman 2001). Here one party in the conflict is ready to forgo his interest for the gain of his counterpart. (3) Dominating (high concern for self and low concern for others) style is characterized by the aggressive mentality of the disputant. Here he tries to maximize his pie of the cake with no regard to the other party. (4) Avoiding (low concern for self and others) style indicates reluctance of the party to get involved in a conflict and carry it forward. It accompanies behavior like, withdrawal, buck-passing, or sidestepping (Rahim 2002). (5) Compromising (medium level of concern for self and others) implies willingness to follow a mutually satisfactory outcome where both parties are ready to give up something of value to ensure optimum rather than satisfaction (Montes, Rodríguez, and Serrano, 2012).

People differ regarding their preferred style of handling conflict. In fact, the style of conflict handling entails "the general tendency for an individual to display a particular type of conflict behavior repeatedly and across situations" (Cupach \& Canary 1997). Ruble \& Schneer (1994) argued that Conflict-handling styles are relatively stable personal disposition of an individual. However, people may adopt and exercise different styles depending on the situation (Boonsathorn 2007).

\section{Conflict, Culture and Religion}

Culture is considered one of the determinants of conflict handling styles. Volkema \& Bergmann (2001) asserted, "Cultural influences could not and should not be dismissed or ignored when analyzing conflict styles, conflict instruments, and behavioral interpretation." Ting-Toomey \& Kurogi (1998) suggest that a person learns conflict styles through the process of socialization. The culture in which, one is socialized plays a decisive role in determining one's conflict handling style. It is, perhaps, because of the cultural influence on conflict behavior, we see similar issues are disputed in different ways in different cultures (Ross 1993). Ting-Toomey (1985) also explained cultural variation in conflict handling styles along Hall's (1976) high versus low-context scheme of cultural variability. Hofstede (1984) singled out individualism-collectivism as the central dimension differentiating cultures. Rahim (2001) maintained that people from individualistic cultures prefer a dominating or obliging style to resolve their conflicts. Elsayed-Ekhouly \& Buda (1996) observed that Arab executives (collectivists) intended to use integrating and avoiding style in handling interpersonal conflicts at work while their American counterparts (individualists) favor obliging, dominating, and compromising style. A similar result was observed in the study of Taiwanese (collectivists) and American students (individualists) by Trubisky et. al., (1991). Ohbuchi et al. (1999) discovered that participants from the collectivist culture of Japan emphasized avoidance styles in conflict while the US participants were more assertive, dominating, and active in their conflict handling approaches. Wekhian (2015) found that first-generation Arab immigrants in the USA identified themselves with collectivism, believed to have a higher level of religiosity, and preferred obliging, compromising, integrating, and avoiding conflict handling styles.

The role of religion in shaping conflict-handling styles has also been examined in the literature. Alston (1975) and Geertz (1973) view religion, as the mainstay through which people identify themselves. Wilson and Power (2004), in their study comparing Australian Christians and Muslims, found that the groups of Christians and Muslims with low religiosity preferred collaborative (integrating) style while the Muslims with higher religiosity have a tendency to prefer compromising style. Croucher (2011) investigated the influence of religion, specifically Islam and Christianity in Western Europe, on the participants' preferred style of interpersonal conflicts. He did not a significant impact of religion on participants' preference of conflict handling styles. He 
observed the Muslims have preference for compromising and obliging styles while Christians favored dominating forms.

\section{Conflict and Islam}

Islam is one of the prominent world religions. The word, Islam is derived from the Arabic word Salam, which means peace. The life of a Muslim is guided by two primary divine sources: The Holy Quran and the Sunnah. The Holy Quran, the book believed to be the words of God relayed to Prophet Muhammad (Peace be upon him) through the Angel Gabriel. The Sunnah refers to the deeds and sayings of the Prophet Muhammad, including everything he stated, reported, did, and described.

Islam is a very comprehensive religion, and it deals with every aspect of life. Islamic scholars identified five branches of Islam: (1) Imaniyah (2) Ibadah (3) Muamalah (4) Muasharah and (5) Akhlaq (Al-Nawawi 2001). Imaniyah refers to the belief segment which necessarily entails absolute belief in the oneness of Allah (the essential name of God in Islamic monotheism) and the prophethood of Muhammad (PBUH). It also includes the belief in angels, the Holy books, on the prophets sent by God, on the Day of Judgment, on the fate and the life hereafter. Imaniyah is the foundation of Islam through which a person enters into the fold of Islam and becomes eligible to claim him/herself to be a Muslim. Adherence to other branches makes a Muslim more devotee. Ibadah refers to the worship to Allah in the form of daily prayer, paying zakat (obligatory payment to the poor by the wealthy Muslims), observing Ramadan (obligatory fasting for one month every year), performing Hajj (Specific rituals to be carried out in a particular time period in Makkah, Saudi Arabia), Zikir (remembrance of Allah) etc. Muamalah indicates the financial dealings, including lending and borrowing money, buying, selling and exchanging goods, business contracts, etc. Muasharah represents rituals and social activities like marriage, birth, death, festivals, rights of parents, relatives, neighbors, etc. Akhlaq refers to interpersonal dealings and character which includes doing good to the people, respecting elders, virtues of forgiveness, being honest in dealings, etc. A devotee Muslim is expected to follow the rulings of Islam in every branch. Conflict, an inevitable part of interpersonal dealings, falls within the purview of Akhlaq. There are verses in the Holy Quran with explicit mentioning about the conflict. Following are such few verses (illustrative):

And hasten for forgiveness from your Rabb (Sustainer) and to a Paradise whose width is as vast as the heavens and the earth, prepared for those who fear Allah. Those who spend freely whether in prosperity or adversity; who hold and check their anger and forgive people and (indeed) Allah loves the doers of good. [Ali'Imran 3: 133-134].

(It is permitted that) An ill-deed be revenged by an ill-deed. However, whoever forgives and resolves his differences (which terminate enmity and lead to friendship as this is even better than forgiveness), then his high reward is Allah's responsibility. (But whoever exceeds the limits while taking revenge let him know) that verily He (Allah) does not like the oppressors. [al Syura 42: 40].

And whenever they get angry they readily forgive. [al-Syura 42: 37]. 
Also, there are explicit sayings in Hadiths (Prophetic remarks) as regard conflict. Following are just a few of them:

Abu Hurairah (RA) narrates that Prophet of Allah (PBUH) said: Musa ibn-Imran (PBUH) said: 0 my Rabb! Who is the most respectable slave to you? Allah, the Almighty and Majestic, replied: He who forgives, despite having the power of to avenge. [Baihaqi. cited in Kandhlavi (2014), p.417 (62)]

Abu Hurairah (RA) narrates that a person requested Prophet of Allah (PBUH): Advise me. He said, Do not get angry. The man repeated this several times, and he replied: Do not get angry. [Bukhari, cited in Kandhlavi (2014), p.419(67)]

Abu Hurairah (RA) narrates that Prophet of Allah (PBUH) said: The Powerful is not he who knocks down others; undoubtedly the powerful is the one who controls himself in a fit of anger. [Bukhari, cited in Kandhlavi (2014: 419 (68)].

Aishah (RA), wife of Prophet of Allah (PBUH) narrates that Rasulullah (PBUH) said: O'Aishah! Verily, Allah is kind and loves kindness. Whatever He confers for kindness is neither conferred upon being harsh nor through any other means except it. [Muslim, cited in Kandhlavi (2014: 421 (76)].

Besides, there are many instances from the life of the Prophet Muhammad (PBUH) that demonstrate the Islamic way of handling conflict. The following story may be a glaring example in this regard: "At the early years of Prophethood, Muhammad (PBUH) started preaching in Makkah amid fierce opposition and most of the people of Makkah negated his invitation with harsh behavior. During that time, one lady, out of anger and betray with the message of the Prophet, used to throw trash on his way on a regular basis. The Prophet used to clean them every day to find his way. One day he found no trash in the street. So immediately he rushed to the house of that lady to know about her wellbeing and discovered her in the sick bed. Upon this, he tried his best to help her to back to her health." (Harun, 2000).

Thus the Quran, Hadith and the deeds of the Prophet (PBUH) persuasively indicate, that Islam, in the case of conflict, overwhelmingly emphasize on 'concern for others' over 'concern for self' in the form of forgiveness, kindness and overpowering one's anger. Thus, based on conventional dimensions of 'concern for self' and 'concern for others,' the Islamic view of conflict handling styles take the preference as shown in figure 2 .

Figure 2: Preferred Conflict handling styles under Islam

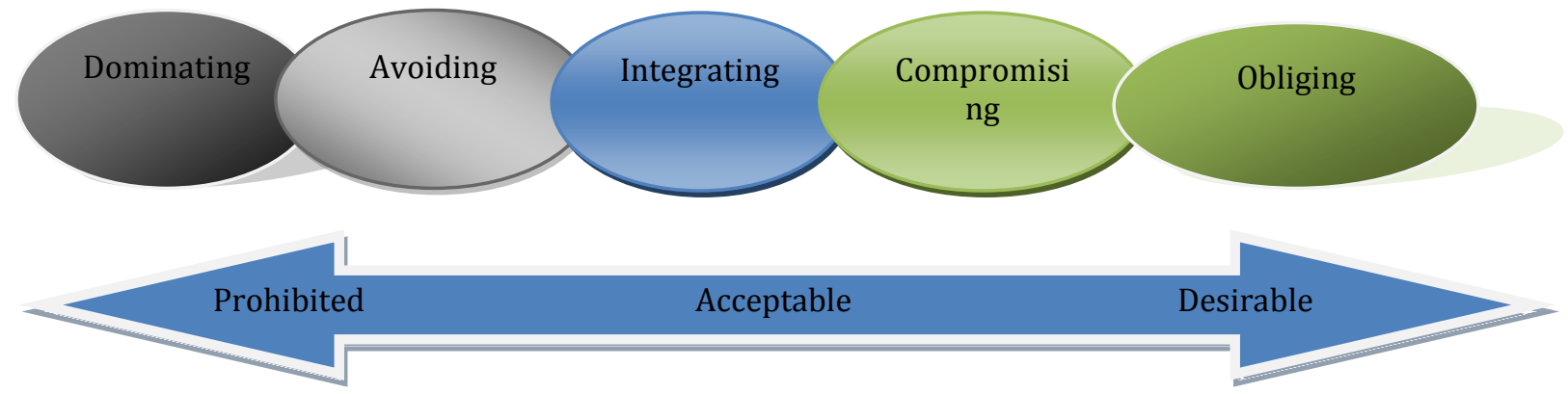


Given the Islamic view of the conflict, we can develop the following hypotheses:

H1: Devotee Muslims prefer obliging style over other styles in handling conflict

H2: Devotee Muslims do not prefer dominating style over other styles in managing conflict.

\title{
Methodology
}

\author{
The Study
}

This is a cross-sectional, quantitative study. Data were collected through a survey with a structured questionnaire. Data analysis was done based on the responses of 344 participants who are the residents of Jeddah City of Saudi Arabia. Among them 64\%, are male, and 36\% are female. The survey was restricted to Saudi Citizens only.

\section{Procedures}

The data for this study was collected by graduate and undergraduate students of a large public university in Saudi Arabia. A total of 700 questionnaires were distributed to the general public located in Jeddah city. The questionnaire was accompanied with a cover letter explaining the purpose of the study and use of information collected through the survey. It was explicitly mentioned that the participation in the study was voluntary. The questionnaire was originally in English. However, to make it understandable to the respondents, each question was translated into Arabic by an expert, and the Arabic translation was reviewed by another expert to ensure the accuracy. Both the English and Arabic versions of the questions were included in the questionnaire. A total of 490 usable questionnaires were returned, indicating a response rate of $70 \%$. However, our focus was to study the conflict handling styles of Devotee Muslims only. As the devotees claim that the religious influence is pervasive in their lives, we confined our study to them only to determine if their conflict handling styles were affected by the religion or not. To explore the influence of religion on the conflict handling of those who deny the influence of religion on their lives does not make much sense. To this end, we classify the religiosity of the respondents along four categories, viz. devotee Muslims, moderate Muslims, confused Muslims and faithless Muslims. Out of 490 effective responses, we identified $344(70.2 \%)$ as devotee Muslims followed by Moderate (93; 19\%), Confused (45; 9.2\%) and faithless $(08 ; 1.6 \%)$. We, therefore, concentrate our analysis on 344 respondents only. The data were then analyzed using SPSS version 16.0. For data analysis, independent sample T-test and paired T-test were used.

\section{Scales}

\section{Conflict Handling Styles}

Conflict handling styles of individual respondents were measured by using an adapted version of the scale of Johnson (Falikowski 2002). It measures the conflict handling styles of individual respondents in general context rater than in a particular context. The scale includes 15 questions along 5 points (Always, very often, sometimes, not very often and rarely, if ever) to measure five dimensions or styles of resolving a conflict. For each dimension, three items were used. A high score indicates that the respondent shows a greater inclination towards that particular conflict-handling style. The estimated reliability coefficients, Cronbach's Alpha $(\alpha)$ were found to have satisfactory 
level: avoiding (0.71), compromising (0.69), dominating (0.73), integrating (0.71) and obliging (0.68), which is satisfactory according to Nunnally's (1978) guidelines.

Religiosity

Religiosity of the respondents was identified by using the following schema of defining different categories of Muslims. The respondents were asked to check the appropriate box according to his/her state of practicing Islam.

- Devotee Muslim: I am serious about my religion and practice Islam in every aspect of my life

- Moderate Muslim: I pray five times a day but not very serious in practicing Islam in every aspect of my life.

- Confused Muslim: I am a believer but usually don't pray five times a day.

- Faithless Muslim: I am a born Muslim but don't believe in Islamic beliefs and principles

\section{Results}

Table 1 and corresponding graph (Figure 3) indicate the preference for different conflict handling styles by various categories of Muslims. It shows that the devotee Muslims prefer integrating style followed by dominating, avoiding, obliging and compromising style. Moderate Muslims follow an almost similar pattern of preference. Confused Muslims prefer integrating style followed by dominating, compromising, avoiding and obliging while faithless Muslims favor compromising style followed by dominating, integrating, avoiding and obliging styles. However, the insignificant number of confused $(9.2 \%)$ and faithless $(1.6 \%)$ respondents does not allow us to make any sensible conclusion about their styles of preference.

Table1: Mean score of different conflict handing style of Muslims

\begin{tabular}{|l|c|c|c|c|c|}
\hline & Dominating & Integrating & Avoiding & Obliging & Compromising \\
\hline $\begin{array}{l}\text { Devotee Muslims } \\
\text { (344) }\end{array}$ & 3.58 & 3.74 & 3.39 & 3.38 & 3.35 \\
\hline $\begin{array}{l}\text { Moderate Muslims } \\
\text { (93) }\end{array}$ & 3.69 & 3.71 & 3.26 & 3.34 & 3.26 \\
\hline $\begin{array}{l}\text { Confused Muslims } \\
(45)\end{array}$ & 3.64 & 3.75 & 3.32 & 3.23 & 3.47 \\
\hline Faithless Muslims (8) & 3.04 & 3.00 & 2.83 & 2.83 & 3.08 \\
\hline
\end{tabular}


Figure 3: Mean score of different conflict handing style of Muslim

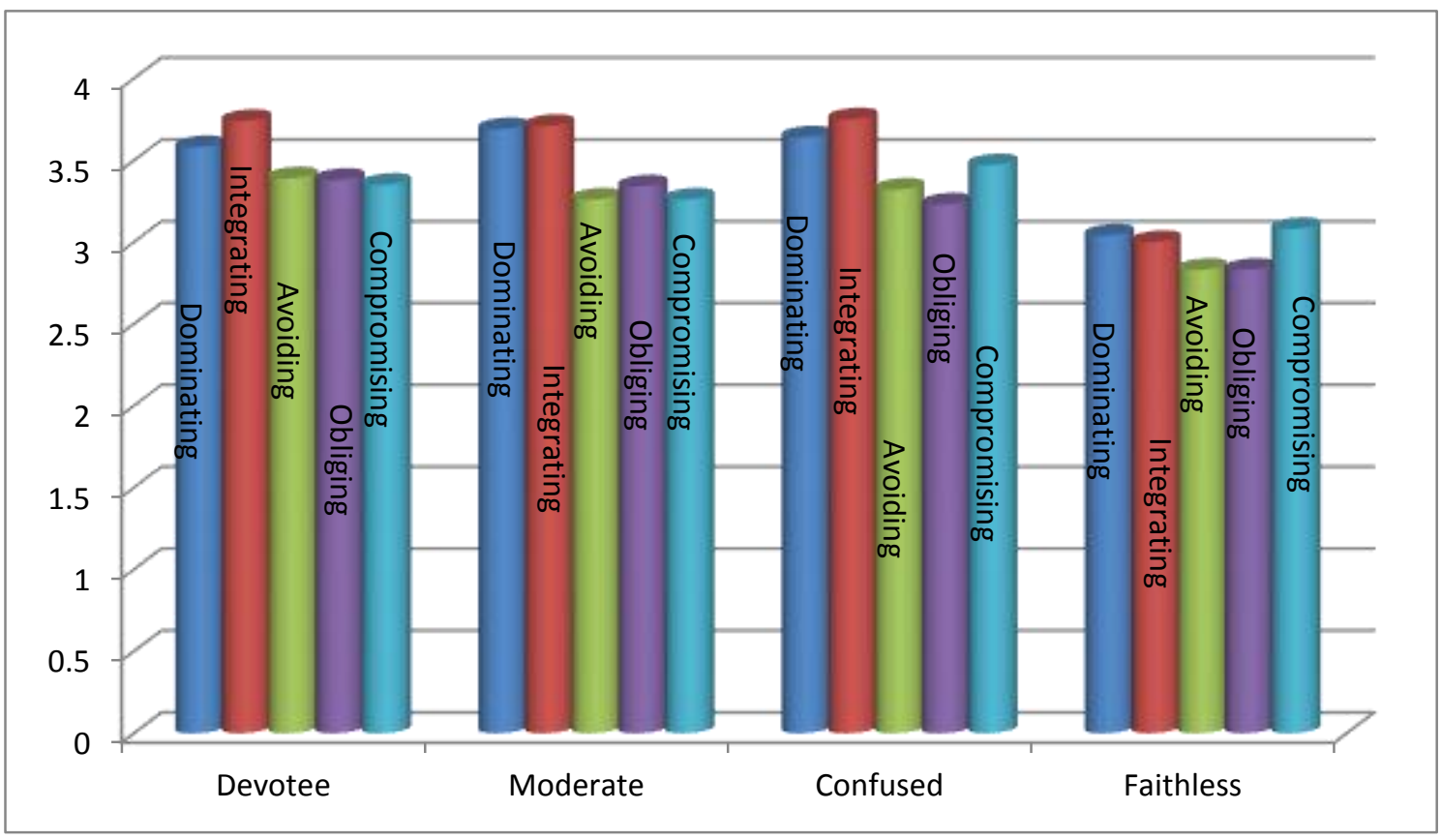

Test of Hypotheses

To test our Hypotheses, H1 and H2 we conducted Paired Sample T Test (Table 2). In line with the hypothesis, pairing obliging style with dominating and integrating styles shows a significant difference in favor of dominating $(\mathrm{p}=.003)$ and integrating $(\mathrm{p}=.000)$ over obliging style which is against our hypothesis, H1. Paring obliging style, with avoiding and compromising shows no significant difference. Therefore, overall, we find evidence to reject our hypothesis, H1. In other words, 'Devotee Muslims prefer obliging style over other styles in handling conflict,' is rejected. Pairing dominating with integrating style indicates a significant preference of the devotee Muslims for integrating $(\mathrm{p}=.015)$ over dominating styles. However, avoiding $(\mathrm{p}=.008)$, obliging $(\mathrm{p}=.003)$ and compromising $(\mathrm{p}=.001)$ style show a significant difference in favor of dominating style. Therefore, overall, the data reject our hypothesis, H2, i.e. 'Devotee Muslims do not prefer dominating style over other styles in handling conflict,' is rejected.

Table 2: Paired Sampled T test between styles

\begin{tabular}{|c|c|c|c|c|c|c|}
\hline \multicolumn{8}{|c|}{ Paring Obliging style with other styles } \\
\hline Pair & Styles & Mean & St. Dev. & \multicolumn{3}{c|}{ Pair Differences } \\
\hline Pair 1 & Obliging & 3.38 & 0.87 & $\mathrm{t}$ & $\mathrm{df}$ & Sig.(2-tailed) \\
& Dominating & 3.58 & 0.91 & -2.946 & 343 & .003 \\
\hline Pair 2 & Obliging & 3.38 & 0.87 & -8.459 & 343 & .000 \\
& Integrating & 3.74 & 0.82 & & & .765 \\
\hline Pair3 & Obliging & 3.38 & 0.87 & -.299 & 343 & .651 \\
& Avoiding & 3.39 & 0.88 & & & \\
\hline Pair 4 & Obliging & 3.38 & 0.87 & .453 & 343 & \\
& Compromising & 3.35 & 0.87 & & & \\
\hline
\end{tabular}




\begin{tabular}{|c|c|c|c|c|c|c|}
\hline \multicolumn{7}{|c|}{ Paring Dominating style with other styles } \\
\hline Pair 1 & Dominating & 3.58 & 0.91 & $\mathrm{t}$ & $\mathrm{df}$ & Sig.(2-tailed) \\
\cline { 5 - 7 } & Integrating & 3.74 & 0.82 & -2.440 & 343 & .015 \\
\hline Pair 2 & Dominating & 3.58 & 0.91 & 2.667 & 343 & .008 \\
& Avoiding & 3.39 & 0.88 & & & .003 \\
\hline Pair 3 & Dominating & 3.58 & 0.91 & 2.946 & 343 & .001 \\
& Obliging & 3.38 & 0.87 & & & \\
\hline Pair4 & Dominating & 3.58 & 0.91 & 3.451 & 343 & \\
& Compromising & 3.35 & 0.87 & & & \\
\hline
\end{tabular}

\section{Discussion}

The devotee Muslims are observed to choose integrating style followed by dominating, avoiding, obliging and compromising style. In line with the Qur'an and Sunnah, the primary source of guidance for Muslims, Devotee Muslims are expected to have a preference for obliging style. However, in the study, it (obliging style) turns out to be the second last choice of the devotees. The results contradict with the study of Wilson \& Power (2004), Polkinghorn \& Byrne (2001), and Croucher (2011). As regard, the preference for integrating style, the finding is partially supported by the culture-based study of Cai \& Fink (2002), Croucher et. al. (2011) and Wekhian (2015).

High preference for integrating and dominating style (both indicate high concern for self) and low preference for obliging (low concern for self while high concern for others) style by the devotee Muslims in a predominantly Muslim society can be attributed to a number of reasons. First, the self-claimed devotee Muslims may have a lack of knowledge or understanding of the comprehensiveness of Islam as a religion. Perhaps, they feel themselves as the devotee as they perform the mandatory ibadah (worships) like praying five times a day, fasting one month in a year, paying obligatory charity (2.5\% of the disposable income) and performing pilgrimage once in a lifetime. To be concerned for handling conflict is, perhaps, considered as 'not so important.' Consequently, they go by their human temperament as regard handling conflict. Second, the majority status of the Saudis in their own country may lead to more aggressive conflict handling styles. Being the son of the soil, they may feel a sense of confidence and boldness in interpersonal conflict. This particular phenomenon is observed in the study of Muslims and Christians in Western Europe by Croucher (2011) where Muslims (minority) preferred more compromising and obliging conflict-handling styles, whereas, Christians (majority) favored the dominating styles. A similar result was also found in the study of Hindu and Muslims in Indian context by Croucher et al. (2011) and Croucher (2013). Third, the survey may be affected by the social acceptability bias. As it is a self-report survey, the respondents have the opportunity to check for a more desirable state for themselves. Thus choice for devotee Muslims may be a bias response in comparison to other categories. It can be sensed from the number of nonresponse for this particular question. It is found that most of the incomplete questionnaire is related to nonresponse to this issue. Fourth, along collectivist-individualist dimensions of culture, Saudi Arabia is usually classified as a collectivist country (Cai and Fink, 2002; Dsilva and Whyte, 1998; Oetzel et al., 2006). Preference for integrating style by the Saudi devotee Muslims matches with the characteristics of a collectivist society. However, their preference for dominating style bids the striking contradiction. It may be explained as an issue of a culture shift. Both integrating and dominating style are based on high concern for self. Perhaps, because of the collectivist orientation, people first try to resolve the conflict in a winwin manner. However, when they fail to do this, they may become more concerned about their own affairs and opt for dominating style, which indicates a feature of individualism. 
To conclude, this study is set out to address the Islamic view of conflict and the preference of using conflict handing styles by Devotee Muslims in Saudi Arabia. Being a comprehensive religion, Islam has specific guidance as regard conflict handling styles. According to Qur'an and the prophetic remarks, Islam prohibits dominating style and encourages obliging style while it considers compromising, integrating and avoiding styles as acceptable for resolving interpersonal conflict. However, the study reveals that there is a striking disparity between the Islamic directives and preference of the self-claimed devotee Muslims. The prohibited dominating style turns out to be the second most preferred style whereas the most encouraged obliging style is observed to be the second least preferred style for the devotee Muslims. It indicates that the self-claimed devotee Muslims have a lack of knowledge about the comprehensiveness of Islam that it is not confined to worshiping of God only; rather it pervades every aspect of human life. In other words, the selfclaimed Muslims maintain a poor level of comprehension about the spirit of Islam. The widespread ignorance of Islamic creed related to interpersonal conflict among the Muslim community may be instrumental in the recent rise of Islamic extremism in different countries. Therefore, the Islamic scholars and the community leaders should emphasize on the totality of Islam through their speeches, actions, and education. It also implies that more rigorous studies are required to explore the psychic makeup of Muslims as regards worship vis-a-vis interpersonal relationships.

\section{References}

Al-Qur'an.

Alston, J. P. 1975. Three Measures of Current Levels of Religiosity. Journal for the Scientific Study of Religion. 14(2): 165-168. doi:10.2307/1384739.

Al-Nawawi, A. Z. M. 2001. Riyadh as-Saaliheen, 'The Gardens of the Righteous.' Beirut: Al-Asrahia Bookstore.

Blake, R.R., and Mouton, J.S. 1964. The Managerial Grid. Houston, TX: Gulf Publishing.

Boonsathorn, W. 2007. Understanding conflict management styles of Thais and Americans in multinational corporations in Thailand. International Journal of Conflict Management.18 (3): 196-221. Available at: http://dx.doi.org/10.1108/10444060710825972.

Cai, D. \& Fink, E. 2002 Conflict style differences between individualists and collectivists. Communication Monographs. 69: 67-87.

Chua, E.G., and Gudykunst, W.B. 1987. Conflict resolution styles in low- and high-context cultures. Communication Research Reports. 4(1): 32-7.

Croucher, S.M. 2011. Muslim and Christian conflict styles in Western Europe. International Journal of Conflict Management. 22(1): 60-74. http://dx.doi.org/10.1108/10444061111103625.

Croucher, S.M. 2011. Self-construal, conflict styles, and religious identification in India. International Journal of Conflict Management. 24(4): 421 - 436. http://dx.doi.org/10.1108/IJCMA-032012-0033

Croucher, S.M., Holody, K.J., Hicks, M.V., Oommen, D. \& DeMaris, A. 2011. An examination of conflict style preferences in India. International Journal of Conflict Management. 22(1): 10-34. http://dx.doi.org/10.1108/10444061111103607.

Cupach, W.R. \& Canary, D.J. 1997. Competence in Interpersonal Conflict. New York: McGraw-Hill.

Dsilva, M. \& Whyte, L. 1998. Cultural differences in conflict styles: Vietnamese refugees and established residents. The Howard Journal of Communications. 9(1): 57-68.

El-Sayed-Ekhouly, S. \& Buda, R. (1996). Organizational conflict: A comparative analysis of conflict styles across cultures. International Journal of Conflict Management. 7(1): 71.

Falikowski, A. 2002. Mastering human relations. Toronto: Prentice Hall. 
Folger JP, Poole MS \& Stutman RK. 2001 Working through Conflict: Strategies far relationships, groups, and organizations (3rd ed.). New York: Addison, Wesley, Longman.

Geertz, C. 1973. The Interpretation of Cultures. New York: Basic Books.

Hall, E. 1976. Beyond Culture. New York: Doubleday.

Harun A.S.M. 2000. Sirat Ibn Hisham -Biography of the Prophet. Cairo: Al-Falah Foundation.

He, Z., Zhu, J.H. \& Peng, S. 2001. Cultural values and conflict resolution in enterprises in diverse cultural settings in China. In G. M. Chen and R. Ma (Eds.), Chinese Conflict Management and Resolution. Westport: Ablex.

Hofstede, G. 1980 Culture's Consequences: International Differences in Work-Related Values. Beverly Hills: Sage.

Hofstede, G. 1984. Culture's Consequences. Garden City, NY: Doubleday.

Kandhlavi, M.Y. 2014. Muntakhab Hadiths (English Translation). Dhaka: Emaniayat Prokashoni.

Montes C, Rodríguez D and Serrano G (2012) Affective choice of conflict management styles. International Journal of Conflict Management. 23(1): 6-18. http://dx.doi.org/10.1108/10444061211199304].

Morris, W.M., et. al. 1998. Conflict management style, accounting for cross-national differences. Journal of International Business Studies. 29(4): 729-747.

Nunnally, J. 1978. Psychometric Theory, 2nd edition. New York: McGraw-Hill.

Oetzel, J.G., Arcos, B., Mabizela, P., Weinman, A.M. \& Zhang, Q. 2006. "Historical, political, and spiritual factors of conflict: understanding conflict perspectives and communication in the Muslim world, China, Colombia, and South Africa", in Oetzel, J.G. \& Ting-Toomey, S. (Eds), The SAGE Handbook of Conflict Communication: Integrating Theory, Research and Practice. California: Sage Publications.

Ohbuchi, K. Fukushima, O, \& Tedeschi, J. T. 1999. Cultural values in conflict management: goal orientation, goal attainment, and tactical decision. Journal of Cross-cultural Psychology. 30: 51-71.

Polkinghorn, B. \& Byrne, S. 2001. Between war and peace: An examination of conflict management styles in four conflict zones. International Journal of Conflict Management. 12(1): 23-46.

Putnam, L.L. \& Poole, M.S. 1987. Conflict and negotiation. In Jablin, FM, Putnam LL, Roberts KH and Porter LW (Eds). Handbook of Organizational Communication: An Interdisciplinary Perspective. Newbury Park: Sage.

Rahim, M.A. 2001. Managing Conflict in Organization (3rd ed.). Westport: Praeger.

Rahim M.A. 2002. Toward a theory of managing organizational conflict. International Journal of Conflict Management. 13(3): 206.

Rahim, M.A. \& Bonoma, T.V. 1979. Managing organizational conflict: A model for diagnosis and intervention. Psychological Reports. 44: 1323-1344.

Randeree, K. 2008. Organizational justice: Migrant worker perceptions in organisations in the United Arab Emirates. Journal of Business Systems, Governance, and Ethics. 3(4): 57-67.

Ross, H. 1993. The Culture of Conflict: Interpretations and Interests in Comparative Perspective. New Haven: Yale University Press.

Ruble, T.L. \& Schneer, J.A. 1994. Gender differences in conflict-handling styles: Less than Meets The Eye?, In, Taylor A., Miller J. B. (Eds). Conflict and Gender, Cresskill. New Jersey: Hampton Press.

Thomas, K.W. 1976. Conflict and conflict management. In M. Dunnette (Ed.). Handbook of Industrial Psychology. (pp. 889-935). Chicago: Rand McNally. 
Ting-Toomey, S. 1985. Toward a theory of conflict and culture. In Gudykunst W, Stewart P \& TingToomey S (Eds). Communication, Culture, and Organizational Processes. Beverly Hills: Sage Publications.

Ting-Toomey, S. \& Kurogi, A. 1998. Facework competence in intercultural conflict: an updated facenegotiation theory. International Journal of Intercultural Relations. 22(2): 187-225.

Ting-Toomey, S., Yee-Jung, K.K., Shapiro, R.B., Wright, T.J. \& Oetzel, G. (2000). Ethnic/cultural identity salience and conflict styles in four US ethnic groups. International Journal of Intercultural Relations. 24(1): 47-81. http://dx.doi.org/10.1016/S0147-1767(99)00023-1.

Tjosvold, D. \& Wong, A. S. H. 2004. Innovating across cultural boundaries: Applying conflict theory to develop a common approach. International Negotiation. 9(2): 291-313. doi: $10.1163 / 1571806042402983$.

Trubisky, P., Ting-Toomey, S. \& Lin, S. 1991. The influence of individualism-collectivism and selfmonitoring on conflict styles. International Journal of Intercultural Relations. 15: 65-84.

Volkema, R.J. \& Bergmann, T.J. 2001. Conflict styles as indicators of behavioral patterns in interpersonal conflict. The Journal of Social Psychology. 135(11): 5-15.

Wekhian, J.A. 2015. Conflict Management Styles in the Workplace: A Study of First Generation Arab Muslim Immigrants in the United States. International Journal of Business and Management. 10 (11): 24-42.

Wilson, R. \& Power, M.R. 2004. Conflict resolution styles among Australian Christians and Muslims. Humanities and Social Sciences Papers 7. 